M. Jametti, M. Joanis

Electoral competition as a determinant of fiscal decentralization

Quaderno N. 11-07

Decanato della Facoltà di Scienze economiche

Via G. Buffi, $13 \mathrm{CH}-6900$ Lugano 


\title{
Electoral Competition as a Determinant of Fiscal Decentralization*
}

\author{
Mario Jametti ${ }^{\dagger}$ \\ University of Lugano, Switzerland \\ CESifo
}

\author{
Marcelin Joanis ${ }^{\ddagger}$ \\ University of Sherbrooke, Canada \\ GREDI \\ CIRANO
}

August 26, 2011

\begin{abstract}
Fiscal decentralization is high on the agenda in policy fora. This paper empirically investigates the underlying causes of fiscal decentralization, based on the predictions of a simple political economy model. We argue that the likeliness that a central government engages in devolution of powers depends in important ways on the political forces that it faces, the theory's main insight being that the central government's electoral strength should, all else being equal, decrease that government's share of spending. Consistent with the model's predictions, empirical results from a panel of democracies support the relevance of political factors as determinants of fiscal decentralization. The relationship between central government electoral strength and both expenditure and revenue centralization emerges as negative and non-linear.

Keywords: Fiscal decentralization; Fiscal federalism; Vertical interactions; Partial Decentralization; Elections

JEL codes: H77, D72, H11

$<$ Tables and Figures at end $>$
\end{abstract}

\footnotetext{
${ }^{*}$ We wish to thank Toke Aidt, Massimo Bordignon, Bob Inman, Sonia Paty and Nicolas Sahuguet for insightful comments, and Youri Chassin for his help with data collection. This paper has been presented, under the title "Determinants of Fiscal Decentralization: Political Economy Aspects" at Cambridge University, CESifo-Munich, Augsburg University, University of Brescia, National Tax Association (Denver 2009), IIPF (Uppsala 2010), SIEP (Pavia 2010), SCSE (Québec 2010), "New issues on fiscal federalism and tax competition" workshop (Lyon 2010) and SSES (Fribourg 2010). Financial support from the Institut d'Economia de Barcelona (IEB) is greatfully acknowledged. The responsibility for any error remains ours.

${ }^{\dagger}$ Institute for Microeconomics and Public Economics (MecoP), University of Lugano, Via G. Buffi 6, 6904 Lugano, Switzerland; e-mail: mario.jametti@usi.ch. Also affiliated with the Swiss Public Administration Network (SPAN).

${ }^{\ddagger}$ Corresponding author: Department of Economics, Université de Sherbrooke, Faculté d'administration, 2500 boul. de l'Université, Sherbrooke (Québec), Canada, J1K 2R1; e-mail: marcelin.joanis@usherbrooke.ca.
} 


\section{Introduction}

Sub-central governments enjoy larger degrees of competence in revenue and expenditure decisions, a trend that has been documented empirically (Arzaghi and Henderson, 2005). What are the determinants of this trend? And what are the channels through which decentralization is achieved? These questions, while on top of the policy agenda, have been relatively little explored.

In this paper we explore the political determinants of fiscal decentralization. In particular, we argue that the likeliness that a central government engages in transfer of powers depends in important ways on the political forces that it faces, the theory's main insight being that the central government's electoral strength should, all else being equal, decrease that government's share of spending. In the model, rents associated with holding office and citizen welfare are substitutes in the central politician's objective function. Citizen welfare depends, in turn, on a combination of public goods produced by both the central government and local governments. In this framework, central politicians may tend to increase their spending on the central public good for electoral purposes. Yet, accumulated political capital weakens this incentive for strong central politicians, making them more likely to be responsive to citizen welfare. While this reponsiveness does imply spending on the central government's own public good, it also involves the devolution of spending powers to local governments provided that central and local public goods are complements. Thus our theoretical perspective links the electoral prospects of central governments (government strenght) to their willingness to devolve spending responsibilities to local governments (fiscal decentralization).

While an important literature has documented an empirical relationship between electoral competition and fiscal policy - either from the macro perspective of 'electoral budget cycles'1

\footnotetext{
${ }^{1}$ See Brender and Drazen's (2005) important cross-country work.
} 
or the micro perspective of 'redistributive politics' ${ }^{2}$ - the conceptually close empirical literature on the determinants of fiscal decentralization has been slow to incorporate political variables in the analysis. An early, cross-sectional attempt is Panizza (1999), who finds that country size, income, ethnic fractionalization and the degree of democracy all reduce the degree of fiscal centralization. Similar results are presented by Arzaghi and Henderson (2005), using panel data. A more recent study, also in a panel context, on the determinants of decentralization in Switzerland (Feld et al., 2008) shows that centralization is negatively related to the availability of direct democratic decision-making (referenda), while Stegarescu (2009) documents the role of political integration as a determinant of fiscal decentralization in OECD countries. None of these papers, however, test for the effect of electoral competition on decentralization. Our paper aims at filling this gap, by including in fiscal decentralization regressions a measure of government strenght. ${ }^{3}$ Our analysis is based on a theoretical political economy framework, thus introducing explicitly the effects of political choices on the degree of decentralization. ${ }^{4}$

Using data from a panel of democracies, we explore the role of electoral conditions prevailing at the central level on the degree of both expenditure and revenue centralization. ${ }^{5}$ Fixed effects regressions generally support our theory's prediction together with highlighting a non-linear relationship between centralization and government strength. Overall, we find that electorally

\footnotetext{
${ }^{2}$ For example, on the role played by electoral competition in the geographical allocation of public infrastructure expenditures, see Knight (2004), Cadot et al. (2006) and Joanis (2011).

${ }^{3}$ We measure government strength as the share of seats held by government in parliament. Alternative measures (which we include as controls) are based on political fragmentation indices. Such measures have been used by some authors to test for the "weak government hypothesis" in studies of a single government's fiscal discipline. The weak government hypothesis states that a government formed by a larger number of actors is more prone to the adverse consequences of a common-pool resource problem (Elgie and McMenamin, 2008). On the empirical relationship between fiscal discipline and political fragmentation, see Roubini and Sachs (1989), de Haan and Sturm (1997), de Haan et al. (1999) and Volkerink and de Haan (2001).

${ }^{4}$ Panizza (1999) also presents a theoretical model in which the degree of centralization is endogenously determined. However, the empirical implementation of that model does not focus on electoral variables.

${ }^{5}$ The paper is also related to the large body of empirical research investigating decentralization as a determinant of various economic variables. For example, Oates (1985) relates the size of government to the degree of decentralization, a question that has been taken up by a number of studies (for a survey, see Feld et al., 2003). Thus, decentralization often features as an explanatory variable in empirical research on fiscal federalism.
} 
strong central governments tend to be associated with lower levels of centralization. More generally, these results suggest that electoral variables rightly belong in the set of determinants of fiscal decentralization.

The paper proceeds as follows. Section 2 lays down the theoretical model and derives the main empirically-testable prediction. Section 3 describes the data, with empirical results being presented and discussed in Section 4. The last section concludes.

\section{A Political Economy Model of Decentralization}

This section lays down a simple political economy model of the behaviour of a central government facing a choice between spending centrally and devolving some spending responsibilities to a local level of government. The analysis is cast in the context of a pure moral hazard political agency model, an approach initiated by Barro (1973) and Ferejohn (1986).

\subsection{Model and Main Testable Prediction}

In the first of two periods, the central government chooses a spending policy to maximize a linear combination of expected discounted political rents over the two periods and of voter welfare, subject to the constraint that it needs to seek reelection at the end of the that period. ${ }^{6}$ Its probability of reelection is increasing in spending at the central level.

More specifically, the central government makes decisions over spending on a central public good $\left(g^{c}\right)$ and on the decentralization of some spending responsibilities $\left(g^{l}\right)$ to a local level of government. The objective of the politician in power is:

\footnotetext{
${ }^{6}$ We follow Treisman (2007) and Brülhart and Jametti (2007) in assuming that politicians are neither extreme revenue maximizing Leviathans nor pure welfare maximizers.
} 


$$
\begin{aligned}
& \max _{g^{l}, g^{c}} \theta\left[s_{1}+\beta \sigma s_{2}\right]+(1-\theta) W\left(g^{l}, g^{c}\right) \\
\text { s.t. } s_{1}= & T-g^{l}-g^{c} \\
s_{2}= & T-g^{l},
\end{aligned}
$$

where $s_{t}$ is the political rent extracted at $t=1,2$ and $W$ is social welfare, which is increasing in spending at both the central and regional levels, and $\theta \in] 0,1[$ is the weight of rent extraction. The two constraints determine the amount of rents taken by the central politician in each period, where $T$ represents the (exogenous) fiscal base. The period- 1 devolution decision is durable and reduces the amount of rents that he can take in both periods. Second-period rents are discounted by a time preference factor $(\beta)$ and by the politician's perception of his reelection probability $(\sigma)$. We assume that he is limited to only two terms in office, as such he becomes a lame duck if reelected. ${ }^{7}$ This is reflected in the period- 2 constraint.

We assume a simple form of probabilistic voting, with $\sigma=G\left(\gamma+g^{c}\right)$. G is an increasing and concave function of electoral capital $\gamma+g^{c}$, where the parameter $\gamma$ captures the electoral strenght of the incumbent central politician. ${ }^{8}$ With these assumptions on the electoral process, the federal government's problem yields the following first order conditions:

$$
\begin{aligned}
\hat{g}^{c} & =G^{-1}\left(\frac{1}{\beta}\left[\frac{1-\theta}{\theta} W_{l}^{\prime}-1\right]\right)-\gamma \equiv B-\gamma, \\
\hat{g}^{l} & =\frac{1}{\beta G^{\prime}\left(\gamma+\hat{g}^{c}\right)}\left[\frac{1-\theta}{\theta} W_{c}^{\prime}-1\right]+T,
\end{aligned}
$$

where $W_{j}^{\prime}$ is the partial derivative of social welfare with respect to spending by government $j$,

\footnotetext{
${ }^{7}$ This is an assumption for simplicity. Alternatively, one could assume that spending decisions at the central level $\left(g^{c}\right)$ are over two periods. This complicates the analysis but does not change our general results.

${ }^{8}$ We follow Joanis (2011) in adopting this particular functional form.
} 
and $G^{\prime}$ is the first derivative of $G$. Together, these two equations imply:

$$
\begin{aligned}
\hat{g}^{c} & =B-\gamma, \\
\hat{g}^{l} & =\frac{1}{\beta G^{\prime}(B)}\left[\frac{1-\theta}{\theta} W_{c}^{\prime}-1\right]+T \equiv A,
\end{aligned}
$$

where $A$ and $B$ are functions of exogenous model parameters if $W$ has constant partial derivatives.

In this simple model, electoral strenght linearly reduces the central government's own spending: safe reelection prospects reduce the politician's need to court his electorate by spending on the central public good. Solving, we obtain the following condition for the degree of centralization $(C E N T R A L)$ :

$$
C E N T R A L \equiv \frac{\hat{g}^{c}}{\hat{g}^{c}+\hat{g}^{l}}=\frac{1}{\frac{A}{B-\gamma}+1} .
$$

Thus, the level of centralization depends negatively on electoral strength $(\gamma)$, which is what we will test for in the empirical application. Notably, the relationship is non-linear, something we will also address.

\subsection{Relation to the Theoretical Literature and Confounding Channels}

This simple theoretical model contributes to a small but growing group of models of 'partial' decentralization. In most of the standard fiscal federalism theoretical literature, the devolution of public good provision and financing is assumed to be a binary decision, i.e. expenditures are either provided by the central or the local governments. Based on the "Decentralization Theorem" (Oates, 1972) allocation of public goods and services is guided by a trade-off between internalizing inter-jurisdictional spillovers and scale economies and catering to local 
preferences. ${ }^{9}$ Notably, even what is known as the Second Generation Theory of Fiscal Federalism (Weingast, 2009), while moving away from assuming benevolent governments ${ }^{10}$ to include political dimensions, still essentially remains within a binary choice framework. The recent literature on partial decentralization is devoted to studying instances of multi-level governance departing from the binary allocation of fiscal responsibilities. A key message of this literature is that institutional frameworks characterized by partial decentralization are especially prone to political influences - see Devarajan et al. (2009) and Joanis (2009). ${ }^{11}$

An innovative feature of the theoretical perspective adopted here is its focus on the federal government's key role in influencing the equilibrium degree of (partial) decentralization. The model offers an interesting perspective on the following question: Why would an opportunistic central politician ever let go of some spending responsibilities or revenues? The model predicts that devolution will occur if the central government's reelection prospects are high - i.e. if government strenght, captured in the model by political capital $\gamma$, is high - and if local spending is sufficiently welfare-improving from citizens' perspective.

Our theory thus predicts a monotone, non-linear negative relationship between government strenght and centralization. This relationship depends on two important implicit assumptions.

The first one is related to the debate between the so-called 'swing voter' and 'machine politics' views of electoral politics. Should a government invest more in public good provision when its reelection prospects are uncertain? The implicit assumption in our model is yes: when reelection uncertainty increases (i.e. $\gamma$ decreases), the expected electoral return on spending by the central government goes up (since $G$ exhibits decreasing returns). This is consistent

\footnotetext{
${ }^{9}$ See Epple and Nechyba (2004) for a recent survey.

${ }^{10}$ The standard in the First Generation Theory (Oates, 2003).

${ }^{11}$ The political economy of partial decentralization has received relatively little attention in the literature. Recent exceptions include Brueckner (2009), who studies partial fiscal decentralization in a Tiebout-style framework, and Hatfield and Padro i Miquel's (2008), whose analysis is cast in a tax competition framework. Note that neither of these papers provide an empirical application.
} 
with the Downsian tradition, where an incumbent should be expected to spend most when the election is most uncertain - see, for example, Lindbeck and Weibull (1987). However, a competing view of government behaviour supports the opposite prediction. According to the alternative machine politics view, public spending is a safer investment for strong electorallymotivated governments than for weak ones. This view of government behaviour is consistent with a theoretical perspective first developed by Cox and McCubbins (1986). A more complete theoretical model would nest both views of government behaviour, which have both been shown to be empirically relevant. In our framework, taking into account such machine politics motives could reverse the sign of the correlation between centralization and government strenght. The empirical relevance of these motives will thus tend to make it harder to detect the negative correlation stemming from the mechanism captured by our simple theoretical model.

A second rather strong assumption is the passivity of local governments in the model. While this assumption is in line with recent studies documenting the relatively low degree of autonomy of local governments (e.g. Blöchliger and King, 2006), a more complete model would also take into account the electoral objectives of local politicians. In a closely related model, Joanis (2009) characterizes the vertical interactions between two levels of government that are involved in the provision of a public good, in an environment where imperfect voter information creates a shared accountability problem. An important feature of the model is that the degree of decentralization is endogenous and depends, among other, on the relative political conditions prevailing at each level of government, i.e. the extent to which each level of government can affect its electoral fortunes by contributing to the public good. Specifically, the model predicts that the degree of centralization is positively associated with the ratio of the electoral uncertainty prevailing at the local level on the electoral uncertainty at the central level. Thus, the sign of the correlation between central government strength and centralization 
predicted above could be reversed by vertical interactions between the center and the local governments. Again, the empirical relevance of this mechanism will make it harder to estimate the predicted negative correlation between government strenght and centralization.

This discussion of potentially confounding channels reinforces the appeal of an empirical test of our theory.

\section{Empirical Framework and Data}

We estimate the following general model:

$$
C E N T R A L_{j t}=f\left(\gamma_{j t} \mid \mathbf{P}_{j t}, \mathbf{X}_{j t}\right)
$$

where $\gamma$ corresponds to a variable measuring central government strength, $\mathbf{P}$ are other political variables, and $\mathbf{X}$ are non-political control variables.

We assembled a new database combining information from four sources: the IMF's Government Financial Statistics (GFS); the World Bank's Dataset of Political Indicators (DPI) and World Development Indicators (WDI); and the Polity 2 dataset from the University of Maryland. We avail of an unbalanced panel of a total of 107 countries $(j)$ with yearly observations $(t)$ for the period 1990 to $2006 .^{12}$

From GFS we included data on expenditures and revenues of different levels of government (central, state and local). We have used this information to construct our measures of centralization. DPI contains information on the political system of each country as well as a vast array of electoral variables, such as party composition and strength of national governments

\footnotetext{
${ }^{12} \mathrm{~A}$ total of 104 countries present at least one year of central government expenditure. The countries of former Yugoslavia are considered individually in our dataset. Note that our dataset includes all the countries of Panizza (1999) except: Central African Republic, Guatemala, Honduras, Iraq, Jordan, Kenya, Malawi, New Zealand, Senegal, Sri Lanka, Yemen and Zaire. However, data is missing in many instances leaving us with at most 64 countries in the sample.
} 
and oppositions. We used this information for our measure of political strength and for political controls. The WDI dataset contains variables concerning overall economic indicators and constitutes our basis for additional control variables. Finally, we use Polity 2 (polity index $>0$ ) to restrict our sample to democracies as we are in a political economy context.

Our dependent variables correspond to centralization ratios:

$$
C E N T R A L=\frac{g^{c}}{g^{c}+g^{s}+g^{l}}
$$

where $g$ is government expenditure or revenues; $c$ is central government; $s$ is state or sub-federal government; and $l$ is local government. Thus, we contrast central government decisions with decisions taken at any sub-central unit. Data is taken from the GFS-Series 1 "Revenue Cash" and 2 "Cash expenditure" for central, state and local governments. ${ }^{13}$ We exclude observations with either expenditure or revenue centralization ratios equal to one, since we are unable to distinguish between absence of sub-central spending and missing data. ${ }^{14}$

We measure government strength $(\gamma)$ as the share of seats held by the government in the legislature. ${ }^{15}$ This variable represents the absolute political strength of the government and is close to our theoretical model.

Our political control variables $\left(\mathbf{P}_{j t}\right)$ are government and opposition Hirschmann-Herfindahl Indices (HHI), i.e. the sum of squared seat shares of government or opposition parties, respectively. ${ }^{16}$ The HHIs measure the breadth of the political spectrum that is part of both

\footnotetext{
${ }^{13}$ We computed overall public expenditure as indicated in (10). GFS contains the government unit "General Government", which, in principle should correspond to the denominator of (10). However, information on this variable is lacking in many instances, and hence we did not use it. Additionally, we have run our regressions using the Series 7 "Outlays". Results do not vary significantly and are available upon request.

${ }^{14}$ Inspection of the data showed that the expenditure centralization ratio in Romania for 1990 was less than $1 \%$. We dropped this observation as well.

${ }^{15}$ All political variables are taken directly from DPI without transformation. Share of seats by government corresponds to the variable $M A J$.

${ }^{16}$ We prefer the HHI, the standard measure of market concentration in IO, to the simple number of parties in government. Alternatively, fractionalization, defined as 1 - HHI, is also used in the literature (see e.g. Elgie
} 
government and opposition. Further we include dummies for left wing government, election year, coalition government if the government $H H I<1$, and minority government for governments with less than $50 \%$ of seats in parliament $(\gamma<0.5)$. Left wing controls for potentially different preferences for decentralization across political views; spending might also be different in electoral years. Finally, coalition and minority government are used as alternatives to the $H H I s$ in some specifications.

Note that DPI presents electoral results. Thus the government composition variables are constant for a particular country over the election cycle (e.g. 4 years). We take this into account for inference by clustering standard errors over the electoral cycle.

The economic controls $\left(\mathbf{X}_{j t}\right)$ correspond to GDP per capita, population and population density, all taken from WDI. Table 1 presents summary statistics.

Figure 1 provides an illustration of our theoretical prediction. For 2002, we plotted the degree of expenditure centralization on government strength $(\gamma)$ finding a slightly negative correlation. Clearly, the countries in our sample differ in many other relevant aspects than political strength. In order to move beyond unconditional correlations we estimate the following version of equation $(9):{ }^{17}$

$$
C E N T R A L_{j t}=\alpha+\beta_{1} \gamma_{j t}+\boldsymbol{\beta}_{2} \mathbf{P}_{j t}+\boldsymbol{\beta}_{3} \mathbf{X}_{j t}+\mathbf{C O U N T R Y}_{j}+\mathbf{Y E A R}_{t}+\varepsilon_{j t},
$$

where COUNTRY $_{j}$ is a vector of country fixed effects, and $\mathbf{Y E A R} \mathbf{R}_{t}$ is a vector of year effects.

We estimate the model for both expenditure and revenue centralization as the dependent and McMenamin, 2008).

${ }^{17}$ Using Stata 11, we cannot estimate panel fixed effects models with our level of clustering. Thus we included both a vector of country and time dummies. However, the reported $R^{2}$ correspond to the within R-squares from (country) fixed effect regressions. 
variable. To allow for the non-linear effect indicated by the theoretical model, we estimate all specifications including the square and cube of $\gamma \cdot{ }^{18}$

We use fixed effects estimation to control for any country specific constant effects. This is different from Panizza (1999) and Arzaghi and Henderson (2005), although they also use GFS data. The first only considers a cross-section while the latter use random effects model. Their focus is mainly on aspects that are country-specific and fixed over time, while our focus is on time varying government strength. Many of the variables used in these earlier papers enter our fixed effects, and thus cannot be accounted for directly.

\section{Estimation and Results}

\subsection{Expenditure Regressions}

Table 2 presents our expenditure centralization specifications. The number of observations varies across models between 457 and 530, including 60 to 64 countries. At the bottom of the table, we present the likelihood and $R^{2}$ as goodness-of-fit measures as well as the joint significance (and $p$-value) of all the political variables.

In the most basic specification, column (1), where we only include government seat share $(\gamma)$ and the fixed effects, we find a negative effect of government strength on centralization, as predicted by theory. The effect is not statistically significant, however. In column (2) we include economic controls $\left(\mathbf{X}_{j t}\right)$. We use logs of income per capita, population and population density. Further, we lag income one period anticipating the time elapsing between economic and political decision making. Including economic controls improves the fit of the model significantly, as illustrated by the increase in the $R^{2}$ from 0.003 to 0.33 . The coefficient on

\footnotetext{
${ }^{18}$ We choose a cubic specification for two reasons. First, political incentives might be different for very week or very strong governments. A quadratic specification does not allow for this. Further, in our dataset both the $A I C$ and $B I C$ information criteria indicate that the cubic specification is a better fit to the data.
} 
seat share remains negative and is slightly larger in absolute value, while still insignificant. Economic controls are in line with expectations. Higher income increases centralization as does a higher population density. Larger countries, in terms of population, decrease the level of centralization, ceteris paribus.

Columns (3) and (4) present our full models including all political variables. The coefficient value for government strength in column (3) does not vary much and is close to -0.04 . Now it is statistically significant at the $10 \%$-level, while from the other political controls only left wing is significant. Interestingly, governments more on the left side of the political spectrum, while typically expected to increase their own spending, are associated to lower levels of centralization. The two concentration measures (government and opposition HHI) are not significant. Political variables are (marginally) jointly significant at the 10\%-level. Column (4) presents a robustness check on the political variables. We drop the HHIs and include dummies for coalition and minority government. The coefficient value of our main variable does not change much, but we loose statistical significance. Note that additionally to a left wing government, a coalition also reduces the degree of centralization.

We next present the results of our non-linear specification in columns (5) to (8). Controls are identical as in the linear specification and their coefficients do not change much. We loose statistical singificance for left wing in column (7), but coalition in column (8) is significant at the $5 \%$-level.

There is a dramatic change, however, in the precision of the effect of government strength. Across all specifications, all terms of $\gamma$ are highly statistically significant. The overall effect remains negative. The upper panel of Figure 2 plots the cumulative effect of the polynomial coefficients over the range of observed values for political strength. First, the (upper) confidence interval illustrates that the effect is significantly negative over the range observed. Second, the 
empirical effect is fairly constant over medium values of $\gamma$. It appears thus that, via the flexible cubic specification, our main effect varies for extreme values of strength. This makes sense in as much as our model might not adequately capture the incentives of governments facing extreme values of $\gamma$. For instance, values close to zero for $\gamma$ might correspond to situations where the (only slightly) strongest party has very limited decisional power within a government coalition, while values close to one may allow governments to essentially abstract from courting the electorate.

\subsection{Revenue Regressions}

Table 3 presents the same specifications as Table 2 with revenue centralization as the dependent variable. The number of observations varies between 458 and 529, corresponding to 59 to 64 countries.

The effect of government strength on centralization is negative througout all specifications. Mirroring expenditure results, it is not statistically significant in the linear specifications (columns (1) to (4)). Again, if we allow for the more flexible cubic specification, the precision of the coefficients increases manyfold and the overall effect is (significantly) negative. The cumulative effect is illustrated in the lower panel of Figure 2.

The economic controls contribute largely to the fit of the model. Their effects (and coefficient magnitudes) are highly similar to the expenditures regressions.

From the other political controls we observe that the opposition HHI is significant and negative both in the linear and cubic specification. Hence, a more dispersed political opposition reduces the degree of centralization. Further, in the non-linear specification a coalition reduces centralization. 


\subsection{Discussion of Results}

We consistently find, across all specifications, that more government strength leads to a lower degree of centralization. Controlling for other political aspects renders the effect significant (in the expenditure regressions), while allowing for a non-linear effect renders it highly significant.

We would argue that this is an important and relevant result. Our country panel allows to estimate the average effect of $\gamma$, controlling for a wide range of other determinants of centralization, in particular everything that is country-specific via fixed effects. Hence, our results confirm our theoretical prior that stronger politicians have a weaker incentive to spend by themselves on public good provision, since they do not have to invest as heavily in their reelection, thus applying downward pressure on the centralization ratio.

The magnitude of the effect, however, does not appear to be very large when one considers the linear specification. Based on Table 2 column (3) an increase in government strength from the first decile $(=0.56)$ to the ninth decile $(=0.94)$ implies a decrease in the level of decentralization of 1.5 percentage points, representing about $2 \%$ evaluated at the mean $(=0.77)$. The effect is stronger in the cubic specification. This is illustrated in Figure 2, indicating an overall effect of government strength of roughly -0.2 evaluated at the mean. Here an increase in $\gamma$ from the first to the ninth decile implies a reduction in centralization of 5.6 percentage points, equal to $7.5 \%$ evaluated at the mean.

While the sign and magnitude of our coefficients are stable across specifications, we do not obtain statistical significance particularly in the linear specification. On the one hand, this confirms our theoretical prior, pointing toward a non-linear relationship. Intuitively, gov-

ernments that are at either side of the range of $\gamma$ might be exposed to other incentives than governments with medium strength. On the other hand, our approach to inference, clustering 
at the electoral cycle, is quite conservative.

While our results are robust to a number of different specifications, they must be interpreted with caution given some caveats. First, the GFS are often criticized for their frequent missing data points and for hard-to-interpret variations in revenue and expenditure items for some countries. However, to date, they remain the only comprehensive data source if one wants to look at determinants of decentralization in a cross-country context including less developped countries. ${ }^{19}$ Second, unobserved preferences of the electorate jointly determine political strength and the level of decentralization, thus creating an endogeneity problem. We would argue that these preferences can be considered fairly stable over the period covered by our data and that the problem is thus attenuated by the inclusion of country fixed effects. Finally, and in our opinion most importantly, our theoretical model assumes passive sub-federal governments. This is in great part driven by the availability of data, as we do not have political indicators at the sub-federal level. Yet, as discussed above, sub-federal governments interact with central government decisions in ways that may well reverse the channel highlighted by our theory.

\section{Conclusion}

Does electoral competition affect the degree of (de-)centralization in a federation? We address this question empirically based on a simple political economy model. Our theoretical prediction is that the degree of centralization is inversely related to the electoral strength of the central government. The intuition behind this is that a strong government has a lesser incentive to court its electorate by contributing to the public good. This in turn reduces the degree of centralization.

\footnotetext{
${ }^{19}$ Given the absence of better data, GFS data are widely used (and published). Examples are: the directly related Panizza (1999) and Arzaghi and Henderson (2005); and the more recent Enikolopov and Zhuravskaya (2007) and Teobaldelli (2011).
} 
We test this prediction using a panel of countries with yearly observations between 1990 and 2006. In our estimates we consistently find that electoral strength, measured as the share of seats held by government in parliament, reduces the level of centralization. Thus our results confirm our theoretical prior. We identify a highly significant non-linear (cubic) relationship between government strength and centralization.

While the cross-country analysis presented in this paper remains exploratory given the caveats discussed in the previous section, we are confident that our analysis is a useful stepping stone to advance our understanding of key political economy aspects of decentralization. We extend the analysis precursored by Panizza (1999) and Arzaghi and Henderson (2005) by introducing in a structured way electoral politics as a determinant of decentralization. Some of the issues mentioned above could potentially be adressed, in further research, by considering within-country data. As such, this paper is part of a broader, ongoing research agenda. Nevertheless, the analysis is already suggestive of implications for policy design, highlighting the need for decentralization reforms to take into account the reality of the political process. With decentralization of expenditure responsibilities being an increasingly pervasive institution in both developed and developing countries, this paper indicates a need to shift the policy focus from whether decentralization is desirable to how decentralization is actually implemented. 


\section{References}

[1] Arzaghi, M. and J. V. Henderson (2005). "Why Countries are Fiscally Decentralizing?" Journal of Public Economics, 89, 1157-1189.

[2] Barro, R. (1973). "The Control of Politicians: An Economic Model," Public Choice, 14, 19-42.

[3] Blöchliger, H. and D. King (2006). "Less Than You thought: the Fiscal Autonomy of Sub-Central Governments," OECD Economics Studies, 43, 155-188.

[4] Brender, A. and A. Drazen (2005). "Political budget cycle in new versus established democracies," Journal of Monetary Economics, 52, 1271-1295.

[5] Brueckner, J. K. (2009). "Partial fiscal decentralization," Regional Science and Urban Economics, 39(1), 23-32, January.

[6] Brülhart, M. and M. Jametti (2007). "Does tax competition tame the Leviathan?," CEPR Discussion Paper 6606.

[7] Cadot, O., L.-H. Röller and A. Stephan (2006). "Contribution to productivity or pork barrel? The two faces of infrastructure investment," Journal of Public Economics, 90, pp. $1133-1153$.

[8] Cox, G. W. and M. D. McCubbins (1986). "Electoral politics as a distributive game," Journal of Politics, 48, no. 2, 370-389.

[9] de Haan, J. and J.-E. Sturm (1997). "Political and economic determinants of OECD budget deficits and government expenditures: A reinvestigation," European Journal of Political Economy, 13, 739-750. 
[10] de Haan, J., J.-E. Sturm, and G. Beekhuis (1999). "The weak government thesis: Some new evidence," Public Choice, 101, 163-176.

[11] Devarajan, S., S. Khemani and S. Shah (2009). "The Politics of Partial Decentralization," in Ehtisham Ahmad and Giorgio Brosio (Eds.), Does Decentralization Enhance Service Delivery And Poverty Reduction?, Edward Elgar.

[12] Elgie, R. and I. McMenamin (2008). "Political fragmentation, fiscal deficits and political institutionalisation," Public Choice, 136, 255-267.

[13] Enikolopov, R. and E. Zhuravskaya (2007). "Decentralization and political institutions," Journal of Public Economics, 91, 2261-2290.

[14] Epple, D. and Th. Nechyba (2004). "Fiscal Decentralization," in J. V. Henderson and J.-F. Thisse (Eds.), Handbook of Regional and Urban Economics Vol 4 - Cities and Geography, Elsevier - North Holland.

[15] Feld, L. P., G. Kirchgässner and C. A. Schaltegger (2010). "Decentralized Taxation and the Size of Government: Evidence from Swiss State and Local Governments," Southern Economic Journal, 77(1), 27-48.

[16] Feld, L. P., C. A. Schaltegger and J. Schnellenbach (2008). "On Government Centralization and Fiscal Referendums," European Economic Review, 52, 611-645.

[17] Ferejohn, J. (1986). "Incumbent Performance and Electoral Control," Public Choice, 50, $5-25$.

[18] Hatfield, J. W. and G. Padro i Miquel (2008). "A Political Economy Theory of Partial Decentralization," NBER Working Papers 14628. 
[19] Knight, B. (2004). "Parochial interests and the centralized provision of local public goods: Evidence from congressional voting on transportation projects," Journal of Public Economics, 88, 845-866.

[20] Joanis, M. (2009). "Intertwined Federalism: Accountability Problems under Partial Decentralization," CIRANO working paper 2009-s39.

[21] Joanis, M. (2011). "The Road to Power: Partisan Loyalty and the Centralized Provision of Local Infrastructure," Public Choice, 146, 117-143.

[22] Lindbeck, A. and J. W. Weibull (1987). "Balanced-budget redistribution as the outcome of political competition," Public Choice, 52(3), 273-297.

[23] Oates, W. E. (1972). Fiscal Federalism, New York: Harcourt Brace.

[24] Oates, W. E. (1985). "Searching for Leviathan: An Empirical Study," American Economic Review, 75, 748-757.

[25] Oates, W. E. (2003). "Toward a Second-Generation Theory of Fiscal Federalism," International Tax and Public Finance, 12, 349-373.

[26] Panizza, U. (1999). "On the Determinants of Fiscal Centralization: Theory and Evidence," Journal of Public Economics, 74, 97-139.

[27] Roubini, N. and J. Sachs (1989). "Government spending and budget deficits in the industrial countries," Economic Policy, 8, 99-132.

[28] Stegarescu, D. (2009). "The effects of economic and political integration on fiscal decentralization: Evidence from OECD countries," Canadian Journal of Economics, 42(2), 694-718. 
[29] Teobaldelli, D. (2011). "Federalism and the shadow economy," Public Choice, 146, 269-289.

[30] Treisman, D. (2007). The Architecture of Government: Rethinking Political Decentralization, Cambridge: Cambridge University Press.

[31] Volkerink, B. and J. de Haan (2001). "Fragmented government effects on fiscal policy: New evidence," Public Choice, 109, 221-242.

[32] Weingast, B. R. (2009). "Second Generation Fiscal Federalism: The Implications of Fiscal Incentives," Journal of Urban Economics, 65, 279-293. 
Figure 1: Electoral Strength and Centralization

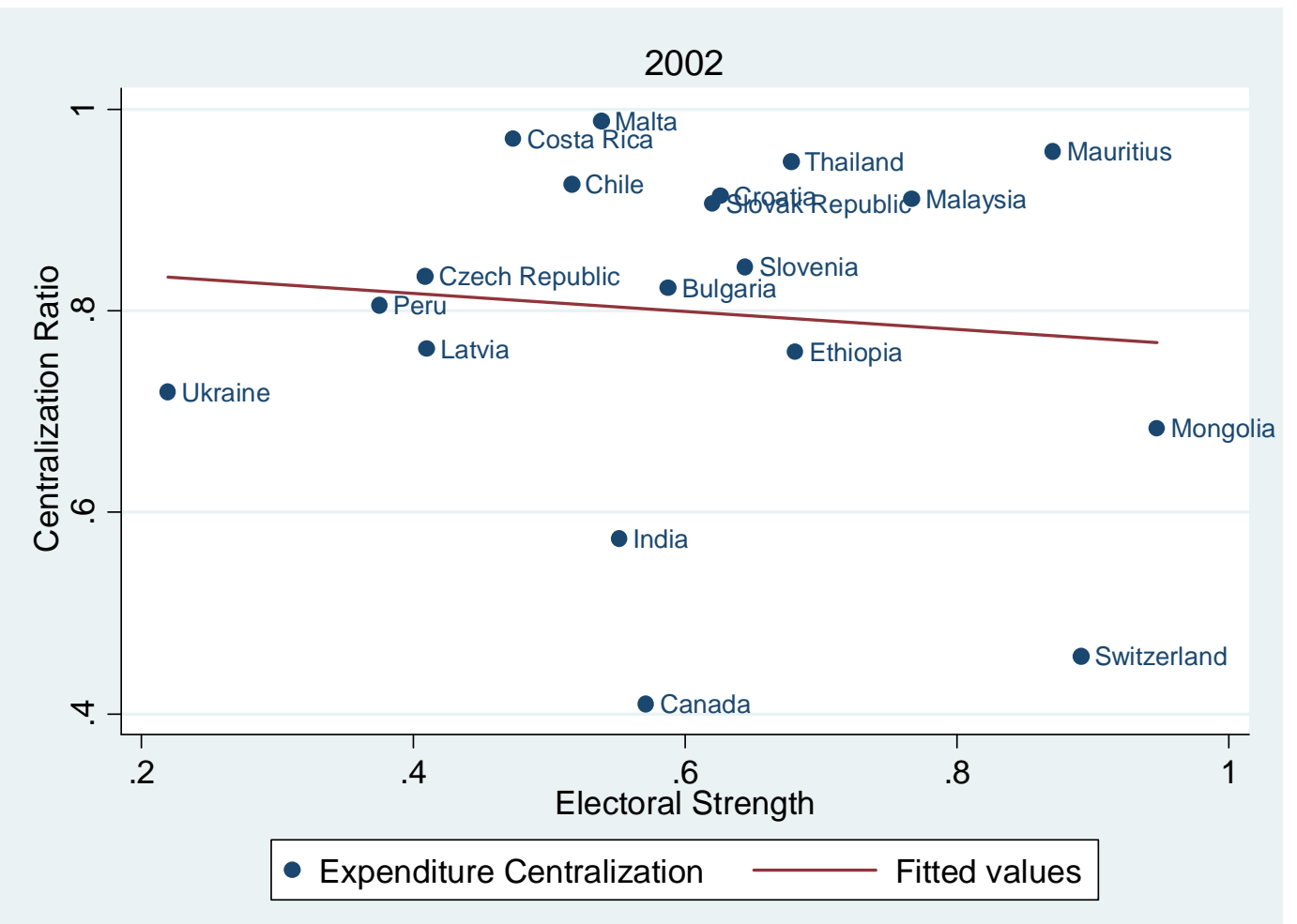


Figure 2: Cumulative Effect of Political Strength on Centralization

- Non-linear Specification
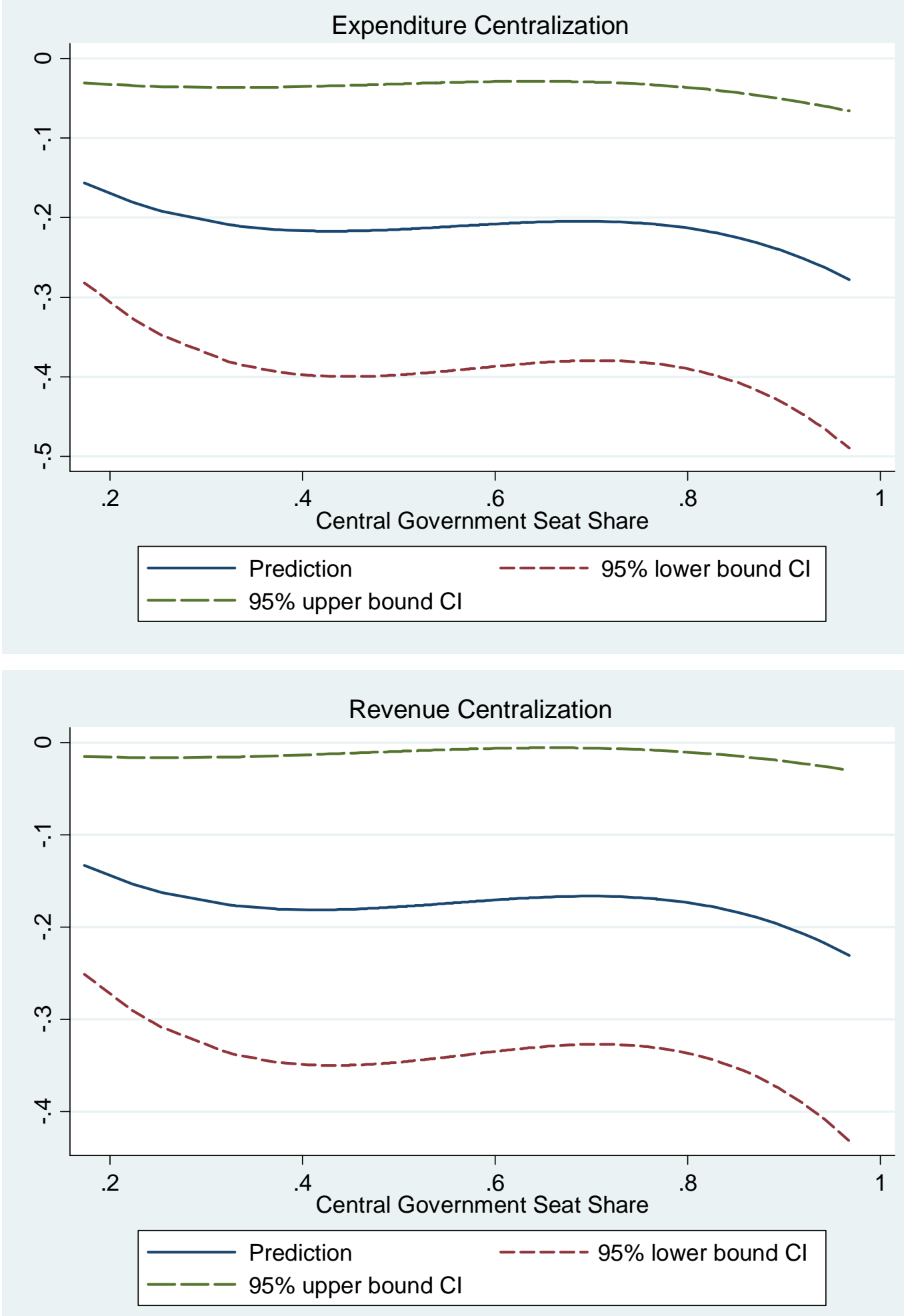
Table 1

Summary Statistics

\begin{tabular}{l|ccccc}
\hline \hline \multicolumn{1}{c|}{ Variable } & Observations & Mean & Std. Dev. & Min & Max \\
\hline Expenditure Centralization & 532 & 0.77 & 0.14 & 0.40 & 0.99 \\
Revenue Centralization & 531 & 0.74 & 0.15 & 0.39 & 0.99 \\
Government seat share $(\gamma)$ & 535 & 0.57 & 0.14 & 0.17 & 0.97 \\
Government Herfindahl index & 537 & 0.67 & 0.28 & 0.11 & 1.00 \\
Opposition Herfindahl index & 534 & 0.46 & 0.22 & 0.07 & 1.00 \\
Left Wing & 537 & 0.37 & 0.48 & 0 & 1 \\
Election Year & 537 & 0.26 & 0.44 & 0 & 1 \\
Coalition Government & 537 & 0.64 & 0.48 & 0 & 1 \\
Minority Government & 537 & 0.27 & 0.44 & 0 & 1 \\
GDP per capita (constant 2000 US\$) & 537 & 10566 & 10636 & 129 & 38407 \\
Population (in millions) & 537 & 53.40 & 162.00 & 0.25 & 1080.00 \\
Population Density & 537 & 117.82 & 148.78 & 1.39 & 1254.06 \\
\hline \hline
\end{tabular}

Sources: GFS, DPI, WDI 
Table 2

\section{Expenditure Regressions}

\begin{tabular}{|c|c|c|c|c|c|c|c|c|}
\hline \multirow{2}{*}{$\begin{array}{l}\text { Dependent Variable = Ratio of Expenditure } \\
\text { Centralization }\end{array}$} & \multicolumn{4}{|c|}{ Linear Political Strength } & \multicolumn{4}{|c|}{$\underset{r}{\text { Non-Linear Political Strength }}$} \\
\hline & (1) & (2) & (3) & (4) & (5) & (6) & (7) & (8) \\
\hline Government seat share $(\gamma)$ & $\begin{array}{l}-0.040 \\
(0.032)\end{array}$ & $\begin{array}{l}-0.045 \\
(0.029)\end{array}$ & $\begin{array}{l}-0.039^{*} \\
(0.022)\end{array}$ & $\begin{array}{l}-0.042 \\
(0.030)\end{array}$ & $\begin{array}{c}-1.397 * * * \\
(0.486)\end{array}$ & $\begin{array}{c}-1.163^{* *} \\
(0.470)\end{array}$ & $\begin{array}{c}-1.272^{* *} \\
(0.507)\end{array}$ & $\begin{array}{c}-1.128^{* *} \\
(0.477)\end{array}$ \\
\hline$\gamma^{2}$ & & & & & $\begin{array}{c}2.626 * * * \\
(0.894)\end{array}$ & $\begin{array}{l}2.224^{* *} \\
(0.854)\end{array}$ & $\begin{array}{c}2.398^{* * *} \\
(0.914)\end{array}$ & $\begin{array}{l}2.247^{* *} \\
(0.867)\end{array}$ \\
\hline$\gamma^{3}$ & & & & & $\begin{array}{c}-1.560^{* * *} \\
(0.526)\end{array}$ & $\begin{array}{c}-1.345^{* * *} \\
(0.499)\end{array}$ & $\begin{array}{c}-1.426 * * * \\
(0.529)\end{array}$ & $\begin{array}{c}-1.372^{* * *} \\
(0.504)\end{array}$ \\
\hline Government Herfindahl index & & & $\begin{array}{c}0.005 \\
(0.014)\end{array}$ & & & & $\begin{array}{c}0.011 \\
(0.011)\end{array}$ & \\
\hline Opposition Herfindahl index & & & $\begin{array}{l}-0.021 \\
(0.018)\end{array}$ & & & & $\begin{array}{l}-0.023 \\
(0.016)\end{array}$ & \\
\hline Left Wing & & & $\begin{array}{l}-0.010^{*} \\
(0.005)\end{array}$ & $\begin{array}{c}-0.011^{* *} \\
(0.005)\end{array}$ & & & $\begin{array}{l}-0.007 \\
(0.005)\end{array}$ & $\begin{array}{l}-0.008^{*} \\
(0.005)\end{array}$ \\
\hline Election Year & & & $\begin{array}{l}-0.002 \\
(0.003)\end{array}$ & $\begin{array}{l}-0.001 \\
(0.003)\end{array}$ & & & $\begin{array}{l}-0.001 \\
(0.002)\end{array}$ & $\begin{array}{l}-0.001 \\
(0.002)\end{array}$ \\
\hline Coalition Government & & & & $\begin{array}{l}-0.015^{*} \\
(0.008)\end{array}$ & & & & $\begin{array}{c}-0.013^{* *} \\
(0.006)\end{array}$ \\
\hline Minority Government & & & & $\begin{array}{l}-0.006 \\
(0.008)\end{array}$ & & & & $\begin{array}{c}0.008 \\
(0.006)\end{array}$ \\
\hline Lag of Log(GDP per capita) & & $\begin{array}{c}0.098^{* * *} \\
(0.033)\end{array}$ & $\begin{array}{c}0.087^{* * *} \\
(0.033)\end{array}$ & $\begin{array}{l}0.079 * * \\
(0.032)\end{array}$ & & $\begin{array}{c}0.082 * * * \\
(0.028)\end{array}$ & $\begin{array}{l}0.076^{* *} \\
(0.030)\end{array}$ & $\begin{array}{l}0.075^{* *} \\
(0.030)\end{array}$ \\
\hline Log(Population) & & $\begin{array}{c}-2.150^{* * *} \\
(0.459)\end{array}$ & $\begin{array}{c}-2.025^{* * *} \\
(0.602)\end{array}$ & $\begin{array}{c}-2.582^{* * *} \\
(0.561)\end{array}$ & & $\begin{array}{c}-1.720^{* * *} \\
(0.450)\end{array}$ & $\begin{array}{c}-1.696^{* * *} \\
(0.536)\end{array}$ & $\begin{array}{c}-2.093^{* * *} \\
(0.490)\end{array}$ \\
\hline Log(Population Density) & & $\begin{array}{c}2.017^{* * *} \\
(0.490) \\
\end{array}$ & $\begin{array}{c}1.867^{* * *} \\
(0.620) \\
\end{array}$ & $\begin{array}{c}2.411^{* * *} \\
(0.576) \\
\end{array}$ & & $\begin{array}{c}1.593^{* * *} \\
(0.482) \\
\end{array}$ & $\begin{array}{c}1.553^{* * *} \\
(0.565) \\
\end{array}$ & $\begin{array}{c}1.948^{* * *} \\
(0.514) \\
\end{array}$ \\
\hline Log likelihood & 1199.69 & 1080.28 & 1081.74 & 1090.13 & 1225.10 & 1102.85 & 1103.75 & 1111.00 \\
\hline R-squared & 0.003 & 0.33 & 0.32 & 0.33 & 0.002 & 0.33 & 0.32 & 0.33 \\
\hline Number of Observations & 530 & 459 & 457 & 459 & 530 & 459 & 457 & 459 \\
\hline Number of Countries & 64 & 60 & 60 & 60 & 64 & 60 & 60 & 60 \\
\hline Joint Significance of Political Variables & 1.55 & 2.37 & $1.87^{*}$ & 1.22 & $3.04 * *$ & $2.58^{*}$ & $2.33^{* *}$ & $2.28^{* *}$ \\
\hline $\mathrm{P}$-value & 0.21 & 0.13 & 0.10 & 0.30 & 0.03 & 0.06 & 0.03 & 0.03 \\
\hline
\end{tabular}

Notes: A constant, time effects and country fixed effects included in all regressions.

Standard errors clustered across the electoral cycle.

R-squared presented from fixed effect panel regression. 
Table 3

\section{Revenue Regressions}

\begin{tabular}{|c|c|c|c|c|c|c|c|c|}
\hline \multirow{2}{*}{$\begin{array}{l}\text { Dependent Variable = Ratio of Expenditure } \\
\text { Centralization }\end{array}$} & \multicolumn{4}{|c|}{ Linear Political Strength } & \multicolumn{4}{|c|}{$\underset{r}{N o n-L i n e a r ~ P o l i t i c a l ~ S t r e n g t h ~}$} \\
\hline & (1) & (2) & (3) & (4) & (5) & (6) & (7) & (8) \\
\hline Government seat share $(\gamma)$ & $\begin{array}{l}-0.017 \\
(0.032)\end{array}$ & $\begin{array}{l}-0.021 \\
(0.028)\end{array}$ & $\begin{array}{l}-0.022 \\
(0.024)\end{array}$ & $\begin{array}{l}-0.035 \\
(0.031)\end{array}$ & $\begin{array}{c}-1.070^{* *} \\
(0.483)\end{array}$ & $\begin{array}{c}-0.936^{* *} \\
(0.424)\end{array}$ & $\begin{array}{c}-1.094^{* *} \\
(0.480)\end{array}$ & $\begin{array}{c}-1.001 * * \\
(0.446)\end{array}$ \\
\hline$\gamma^{2}$ & & & & & $\begin{array}{l}2.127^{* *} \\
(0.910)\end{array}$ & $\begin{array}{l}1.847^{* *} \\
(0.787)\end{array}$ & $\begin{array}{l}2.109 * * \\
(0.885)\end{array}$ & $\begin{array}{l}1.953^{* *} \\
(0.811)\end{array}$ \\
\hline$\gamma^{3}$ & & & & & $\begin{array}{c}-1.303^{* *} \\
(0.542)\end{array}$ & $\begin{array}{c}-1.128^{* *} \\
(0.466)\end{array}$ & $\begin{array}{c}-1.265^{* *} \\
(0.520)\end{array}$ & $\begin{array}{c}-1.175^{* *} \\
(0.472)\end{array}$ \\
\hline Government Herfindahl index & & & $\begin{array}{l}-0.001 \\
(0.015)\end{array}$ & & & & $\begin{array}{c}0.003 \\
(0.013)\end{array}$ & \\
\hline Opposition Herfindahl index & & & $\begin{array}{c}-0.039^{* *} \\
(0.019)\end{array}$ & & & & $\begin{array}{c}-0.041^{* *} \\
(0.018)\end{array}$ & \\
\hline Left Wing & & & $\begin{array}{l}-0.004 \\
(0.005)\end{array}$ & $\begin{array}{l}-0.003 \\
(0.005)\end{array}$ & & & $\begin{array}{l}-0.001 \\
(0.005)\end{array}$ & $\begin{array}{l}-0.001 \\
(0.005)\end{array}$ \\
\hline Election Year & & & $\begin{array}{c}0.000 \\
(0.003)\end{array}$ & $\begin{array}{c}0.000 \\
(0.003)\end{array}$ & & & $\begin{array}{c}0.000 \\
(0.002)\end{array}$ & $\begin{array}{c}0.001 \\
(0.002)\end{array}$ \\
\hline Coalition Government & & & & $\begin{array}{l}-0.013 \\
(0.008)\end{array}$ & & & & $\begin{array}{l}-0.012^{*} \\
(0.007)\end{array}$ \\
\hline Minority Government & & & & $\begin{array}{l}-0.011 \\
(0.009)\end{array}$ & & & & $\begin{array}{l}-0.001 \\
(0.009)\end{array}$ \\
\hline Lag of Log(GDP per capita) & & $\begin{array}{l}0.088^{* *} \\
(0.038)\end{array}$ & $\begin{array}{l}0.087^{* *} \\
(0.036)\end{array}$ & $\begin{array}{l}0.073^{* *} \\
(0.035)\end{array}$ & & $\begin{array}{l}0.076^{* *} \\
(0.033)\end{array}$ & $\begin{array}{c}0.077^{* *} \\
(0.032)\end{array}$ & $\begin{array}{c}0.071^{* *} \\
(0.033)\end{array}$ \\
\hline Log(Population) & & $\begin{array}{c}-2.573^{* * *} \\
(0.602)\end{array}$ & $\begin{array}{c}-2.278^{* * *} \\
(0.716)\end{array}$ & $\begin{array}{c}-3.012^{* * *} \\
(0.715)\end{array}$ & & $\begin{array}{c}-2.204^{* * *} \\
(0.549)\end{array}$ & $\begin{array}{c}-1.970 * * * \\
(0.617)\end{array}$ & $\begin{array}{c}-2.600^{* * *} \\
(0.624)\end{array}$ \\
\hline Log(Population Density) & & $\begin{array}{c}2.298^{* * *} \\
(0.639) \\
\end{array}$ & $\begin{array}{c}1.988^{* * *} \\
(0.742) \\
\end{array}$ & $\begin{array}{c}2.713^{* * *} \\
(0.735) \\
\end{array}$ & & $\begin{array}{c}1.937^{* * *} \\
(0.584) \\
\end{array}$ & $\begin{array}{c}1.695 * * * \\
(0.649) \\
\end{array}$ & $\begin{array}{c}2.324^{* * *} \\
(0.648) \\
\end{array}$ \\
\hline Log likelihood & 1142.27 & 1050.05 & 1050.71 & 1056.33 & 1160.27 & 1065.00 & 1066.96 & 1068.33 \\
\hline R-squared & 0.00 & 0.35 & 0.35 & 0.35 & 0.002 & 0.35 & 0.35 & 0.35 \\
\hline Number of Observations & 529 & 458 & 456 & 458 & 529 & 458 & 456 & 458 \\
\hline Number of Countries & 64 & 59 & 59 & 59 & 64 & 59 & 59 & 59 \\
\hline Joint Significance of Political Variables & 0.28 & 0.57 & 1.36 & 0.60 & 1.98 & 2.01 & $2.19 * *$ & 1.35 \\
\hline P-value & 0.59 & 0.45 & 0.24 & 0.70 & 0.12 & 0.11 & 0.04 & 0.23 \\
\hline
\end{tabular}

${ }^{*} \mathrm{p}<0.1,{ }^{* *} \mathrm{p}<0.05, * * * \mathrm{p}<0.01$

Notes: A constant, time effects and country fixed effects included in all regressions.

Standard errors clustered across the electoral cycle.

R-squared presented from fixed effect panel regression. 


\section{QUADERNI DELLA FACOLTÀ}

1998:

P. Balestra, Efficient (and parsimonious) estimation of structural dynamic error component models

1999:

M. Filippini, Cost and scale efficiency in the nursing home sector : evidence from Switzerland

L. Bernardi, I sistemi tributari di oggi : da dove vengono e dove vanno

L.L. Pasinetti, Economic theory and technical progress

G. Barone-Adesi, K. Giannopoulos, L. Vosper, VaR without correlations for portfolios of derivative securities

G. Barone-Adesi, Y. Kim, Incomplete information and the closed-end fund discount

G. Barone-Adesi, W. Allegretto, E. Dinenis, G. Sorwar, Valuation of derivatives based on CKLS interest rate models

M. Filippini, R. Maggi, J. Mägerle, Skalenerträge und optimale Betriebsgrösse bei den schweizerische Privatbahnen

E. Ronchetti, F. Trojani, Robust inference with GMM estimators

G.P. Torricelli, I cambiamenti strutturali dello sviluppo urbano e regionale in Svizzera e

nel Ticino sulla base dei dati dei censimenti federali delle aziende 1985, 1991 e 1995

2000:

E. Barone, G. Barone-Adesi, R. Masera, Requisiti patrimoniali, adeguatezza del capitale e gestione del rischio

G. Barone-Adesi, Does volatility pay?

G. Barone-Adesi, Y. Kim, Incomplete information and the closed-end fund discount

$\mathrm{R}$. Ineichen, Dadi, astragali e gli inizi del calcolo delle probabilità

W. Allegretto, G. Barone-Adesi, E. Dinenis, Y. Lin, G. Sorwar, A new approach to check the free boundary of single factor interest rate put option

G.D.Marangoni, The Leontief Model and Economic Theory

B. Antonioli, R, Fazioli, M. Filippini, // servizio di igiene urbana italiano tra concorrenza e monopolio

L. Crivelli, M. Filippini, D. Lunati. Dimensione ottima degli ospedali in uno Stato federale

L. Buchli, M. Filippini, Estimating the benefits of low flow alleviation in rivers: the case of the Ticino River

L. Bernardi, Fiscalità pubblica centralizzata e federale: aspetti generali e il caso italiano attuale

M. Alderighi, R. Maggi, Adoption and use of new information technology

F. Rossera, The use of log-linear models in transport economics: the problem of

commuters' choice of mode

2001:

M. Filippini, P. Prioni, The influence of ownership on the cost of bus service provision in

Switzerland. An empirical illustration

B. Antonioli, M. Filippini, Optimal size in the waste collection sector

B. Schmitt, La double charge du service de la dette extérieure

L. Crivelli, M. Filippini, D. Lunati, Regulation, ownership and efficiency in the Swiss

nursing home industry

S. Banfi, L. Buchli, M. Filippini, Il valore ricreativo del fiume Ticino per i pescatori

L. Crivelli, M. Filippini, D. Lunati, Effizienz der Pflegeheime in der Schweiz 
2002:

B. Antonioli, M. Filippini, The use of a variable cost function in the regulation of the Italian water industry

B. Antonioli, S. Banfi, M. Filippini, La deregolamentazione del mercato elettrico svizzero e implicazioni a breve termine per l'industria idroelettrica

M. Filippini, J. Wild, M. Kuenzle, Using stochastic frontier analysis for the access price regulation of electricity networks

G. Cassese, On the structure of finitely additive martingales

2003:

M. Filippini, M. Kuenzle, Analisi dell'efficienza di costo delle compagnie di bus italiane e svizzere

C. Cambini, M. Filippini, Competitive tendering and optimal size in the regional bus transportation industry

L. Crivelli, M. Filippini, Federalismo e sistema sanitario svizzero

L. Crivelli, M. Filippini, I. Mosca, Federalismo e spesa sanitaria regionale : analisi empirica per i Cantoni svizzeri

M. Farsi, M. Filippini, Regulation and measuring cost efficiency with panel data models : application to electricity distribution utilities

M. Farsi, M. Filippini, An empirical analysis of cost efficiency in non-profit and public nursing homes

F. Rossera, La distribuzione dei redditi e la loro imposizione fiscale : analisi dei dati fiscali svizzeri

L. Crivelli, G. Domenighetti, M. Filippini, Federalism versus social citizenship :

investigating the preference for equity in health care

M. Farsi, Changes in hospital quality after conversion in ownership status

G. Cozzi, O. Tarola, Mergers, innovations, and inequality

M. Farsi, M. Filippini, M. Kuenzle, Unobserved heterogeneity in stochastic cost frontier models : a comparative analysis

2004:

G. Cassese, An extension of conditional expectation to finitely additive measures

$\mathrm{S}$. Demichelis, O. Tarola, The plant size problem and monopoly pricing

F. Rossera, Struttura dei salari 2000 : valutazioni in base all'inchiesta dell'Ufficio federale di statistica in Ticino

M. Filippini, M. Zola, Economies of scale and cost efficiency in the postal services : empirical evidence from Switzerland

F. Degeorge, F. Derrien, K.L. Womack, Quid pro quo in IPOs : why book-building is dominating auctions

M. Farsi, M. Filippini, W. Greene, Efficiency measurement in network industries : application to the Swiss railway companies

L. Crivelli, M. Filippini, I. Mosca, Federalism and regional health care expenditures : an empirical analysis for the Swiss cantons

S. Alberton, O. Gonzalez, Monitoring a trans-border labour market in view of liberalization : the case of Ticino

M. Filippini, G. Masiero, K. Moschetti, Regional differences in outpatient antibiotic consumption in Switzerland

A.S. Bergantino, S. Bolis, An adaptive conjoint analysis of freight service alternatives :

evaluating the maritime option

2005:

M. Farsi, M. Filippini, An analysis of efficiency and productivity in Swiss hospitals

M. Filippini, G. Masiero, K. Moschetti, Socioeconomic determinants of regional

differences in outpatient antibiotic consumption : evidence from Switzerland 
2006:

M. Farsi, L. Gitto, A statistical analysis of pain relief surgical operations

M. Farsi, G. Ridder, Estimating the out-of-hospital mortality rate using patient discharge data

S. Banfi, M. Farsi, M. Filippini, An empirical analysis of child care demand in Switzerland

L. Crivelli, M. Filippini, Regional public health care spending in Switzerland : an empirical analysis

M. Filippini, B. Lepori, Cost structure, economies of capacity utilization and scope in Swiss higher education institutions

M. Farsi, M. Filippini, Effects of ownership, subsidization and teaching activities on hospital costs in Switzerland

M. Filippini, G. Masiero, K. Moschetti, Small area variations and welfare loss in the use of antibiotics in the community

A. Tchipev, Intermediate products, specialization and the dynamics of wage inequality in the US

A. Tchipev, Technological change and outsourcing : competing or complementary explanations for the rising demand for skills during the 1980s?

2007:

M. Filippini, G. Masiero, K. Moschetti, Characteristics of demand for antibiotics in primary care : an almost ideal demand system approach

G. Masiero, M. Filippini, M. Ferech, H. Goossens, Determinants of outpatient antibiotic consumption in Europe : bacterial resistance and drug prescribers

R. Levaggi, F. Menoncin, Fiscal federalism, patient mobility and the soft budget constraint : a theoretical approach

M. Farsi, The temporal variation of cost-efficiency in Switzerland's hospitals : an application of mixed models

2008

M. Farsi, M. Filippini, D. Lunati, Economies of scale and efficiency measurement in Switzerland's nursing homes

A. Vaona, Inflation persistence, structural breaks and omitted variables : a critical view

A. Vaona, The sensitivity of non parametric misspecification tests to disturbance autocorrelation

A. Vaona, STATA tip : a quick trick to perform a Roy-Zellner test for poolability in STATA

A. Vaona, R. Patuelli, New empirical evidence on local financial development and growth

C. Grimpe, R. Patuelli, Knowledge production in nanomaterials : an application of spatial filtering to regional system of innovation

A. Vaona, G. Ascari, Regional inflation persistence : evidence from Italy

M. Filippini, G. Masiero, K. Moschetti, Dispensing practices and antibiotic use

T. Crossley, M. Jametti, Pension benefit insurance and pension plan portfolio choice

R. Patuelli, A. Vaona, C. Grimpe, Poolability and aggregation problems of regional innovation data : an application to nanomaterial patenting

J.H.L. Oud, H. Folmer, R. Patuelli, P. Nijkamp, A spatial-dependence continuous-time model for regional unemployment in Germany

2009:

J.G. Brida, S. Lionetti, W.A. Risso, Long run economic growth and tourism : inferring from Uruguay

R. Patuelli, D.A. Griffith, M. Tiefelsdorf, P. Nijkamp, Spatial filtering and eigenvector stability : space-time models for German unemployment data

R. Patuelli, A. Reggiani, P. Nijkamp, N. Schanne, Neural networks for cross-sectional employment forecasts : a comparison of model specifications for Germany

A. Cullmann, M. Farsi, M. Filippini, Unobserved heterogeneity and International

benchmarking in public transport

M. Jametti, T. von Ungern-Sternberg, Hurricane insurance in Florida

S. Banfi, M. Filippini, Resource rent taxation and benchmarking : a new perspective for the Swiss hydropower sector 
S. Lionetti, R. Patuelli, Trading cultural goods in the era of digital piracy

M. Filippini, G. Masiero, K. Moschetti, Physician dispensing and antibiotic prescriptions

2010:

Quaderno n. 10-01

R. Patuelli, N. Schanne, D.A. Griffith, P. Nijkamp, Persistent disparities in regional unemployment : application of a spatial filtering approach to local labour markets in Germany

Quaderno n. 10-02

K. Deb, M. Filippini, Public bus transport demand elasticities in India

Quaderno n. 10-03

L. Masiero, R. Maggi, Estimation of indirect cost and evaluation of protective measures

for infrastructure vulnerability : a case study on the transalpine transport corridor

Quaderno n. 10-04

L. Masiero, D.A. Hensher, Analyzing loss aversion and diminishing sensitivity in a freight transport stated choice experiment

Quaderno n. 10-05

L. Masiero, D.A. Hensher, Shift of reference point and implications on behavioral reaction

to gains and losses

Quaderno n. 10-06

J.M. Rose, L. Masiero, A comparison of prospect theory in WTP and preference space Quaderno n. 10-07

M. Filippini, M. Koller, U. Trinkner, Do opening hours and unobserved heterogeneity affect economies of scale and scope in postal outlets?

Quaderno n. 10-08

G. Guerra, R. Patuelli, R. Maggi, Ethnic concentration, cultural identity and immigrant self-employment in Switzerland

Quaderno n. 10-09

S. Lionetti, Tourism productivity : incentives and obstacles to fostering growth

Quaderno n. 10-10

G. Guerra, R. Patuelli, The influence of role models on immigrant self-employment : a spatial analysis for Switzerland

Quaderno n. 10-11

M. Filippini, L. Gonzalez, G. Masiero, Estimating dynamic consumption of antibiotics using panel data : the shadow effect of bacterial resistance

2011:

Quaderno n. 11-01

L. Masiero, J.L. Nicolau, Price sensitivity to tourism activities : looking for determinant factors

Quaderno n. 11-02

L. Masiero, J.L. Nicolau, Finding similar price preferences on tourism activities

Quaderno n. 11-03

L. Masiero, R. Maggi, Accounting for WTP/WTA discrepancy in discrete choice models :

discussion of policy implications based on two freight transport stated choice experiments Quaderno n. 11-04

L. Masiero, J.M. Rose, The role of the reference alternative in the specification of asymmetric discrete choice models 


\section{Quaderno n. 11-05}

D. Engel, T. Mitze, R. Patuelli, J. Reinkowski, Does the support of innovative clusters sustainably foster R\&D activity? Evidence from the German BioRegio and BioProfile contests

Quaderno n. 11-06

L. González, G. Masiero, Disentangling spillover effects of antibiotic consumption : a spatial panel approach

Quaderno n. 11-07

M. Jametti, M. Joanis, Electoral competition as a determinant of fiscal decentralization 